\title{
Kırım-Kongo Kanamalı Ateși: 16 Olgunun Klinik Özelliklerinin ve Laboratuvar Bulgularının Retrospektif Deg̃erlendirilmesi
}

\section{Crimean-Congo Hemorrhagic Fever: Retrospective Evaluation of Clinical Features and Laboratory Findings of 16 Cases}

\author{
Deniz AKYOL'(IID), Esra ERDEM KIVRAK(ID), Hüseyin Aytaç ERDEM'(IID), Hüsnü PULLUKÇU'(IID), \\ Og̃uz Reșat SiPAHi'(iiD), Meltem TAȘBAKAN'(ï)
}

\footnotetext{
${ }^{1}$ Ege Üniversitesi Tıp Fakültesi, İnfeksiyon Hastalıkları ve Klinik Mikrobiyoloji Anabilim Dalı, İzmir, Türkiye

${ }^{2}$ Balıkesir Edremit Devlet Hastanesi, İnfeksiyon Hastalıkları ve Klinik Mikrobiyoloji Klinig̃i, Balıkesir, Türkiye
}

Makale atıfi: Akyol D, Erdem Kıvrak E, Erdem HA, Pullukçu H, Sipahi OR, Taşbakan M. Kırım-kongo kanamalı ateşi: 16 olgunun klinik özelliklerinin ve laboratuvar bulgularının retrospektif değerlendirilmesi. FLORA 2020;25(4):544-8.

ÖZ

Giriş: Kırım Kongo Kanamalı Ateşi (KKKA) sıklıkla kene tutunması ile bulaşan, ateş ve kanamalar ile seyreden zoonotik bir hastalık olup önemli halk sağlığı sorunlarına yol açabilmektedir. Klinik belirtiler ve epidemiyolojik öykü yanında, kan sayımı ve biyokimyasal test sonuçları KKKA için ilk ipuçlarını oluşturmaktadır. Bu çalışmada hastanemizde KKKA tanısı ile takip ve tedavi edilen 16 olgunun retrospektif olarak değerlendirilmesi amaçlanmıştır.

Materyal ve Metod: Kliniğimizde 2009-2019 yılları arasında KKKA tanısı ile takip ve tedavi edilen olgular demografik özellikleri, başvuru yakınmaları, kene öyküsünün varlığı, laboratuvar parametreleri, kan ürünleri replasmanı gerekliliği, hastanede yatış süreleri, ribavirin tedavisi ve bir aylık sağ kalımları açısından retrospektif olarak hasta dosyalarındaki verilerden incelenmiştir.

Bulgular: Kırım Kongo Kanamalı Ateşi tanısı ile 16 olgu [on kadın, altı erkek, ortalama yaş $50.37 \pm 18.01$ (min: 18-max: 79)] çalışmaya dahil edildi. Olguların başvuru yakınmaları ateş yüksekliği (16/16, \%100), halsizlik (16/16,\%100), kanama (9/16, \%56.2), peteşial tarzda döküntü $(7 / 16, \% 43.7)$ ve bulantı-kusma (6/16, \%37.5) şeklindeydi. On dört olguda (\%87.5) kene temas öyküsü bulunurken iki olguda yoktu. Olguların hepsine destek tedavi uygulandı, tamamı damlacık ve temas izolasyonu uygulanarak izlendi. Kan ürünleri replasmanı beş olguya (\%31.2), ribavirin dokuz olguya (\%56.2) uygulandı. Mortalite oranı \%6.3'tü (1/16).

Sonuç: Kırım Kongo Kanamalı Ateşi, ülkemizde endemik olarak görülen bir hastalıktır. Özellikle bahar ve yaz aylarında ateş yüksekliği ve hemogramda sitopeni saptanan hastalarda mutlaka kene ile temas sorgulanmalıdır ve muayenede aranmalıdır.

Anahtar Kelimeler: Kırım-Kongo kanamalı ateşi; Kene; Ribavirin 
ABSTRACT

\title{
Crimean-Congo Hemorrhagic Fever: Retrospective Evaluation of Clinical Features and Laboratory Findings of 16 Cases
}

\author{
Deniz AKYOL', Esra ERDEM KIVRAK², Hüseyin Aytaç ERDEM', Hüsnü PULLUKÇU', Og̃uz Reșat SiPAHi', \\ Meltem TAȘBAKAN ${ }^{1}$
}

\footnotetext{
${ }^{1}$ Department of Infectious Diseases and Clinical Microbiology, Faculty of Medicine, Ege Unıversıty, Izmır, Turkey

${ }^{2}$ Clinic of Infectious Diseases and Clinical Microbiology, Balıkesir Edremit State Hospital, Balıkesir, Turkey
}

Introduction: Crimean-Congo Hemorrhagic Fever (CCHF) is a zoonotic disease frequently transmitted by tick bite and accompanied by fever and bleeding. It may cause important public health problems. Besides clinical symptoms and epidemiological history, blood count and biochemical test results are the first clues for CCHF. In this study, we aimed to retrospectively evaluate 16 patients who were followed and treated due to CCHF in our hospital.

Materials and Methods: The patients who were followed up and treated with CCHF between 2009-2019 in our clinic were evaluated retrospectively in terms of demographic characteristics, presenting complaints, presence of tick history, laboratory parameters, necessity of blood products replacement, hospitalization periods, ribavirin treatment and one-month survival.

Results: Sixteen patients [ten females, six males, mean age $50.37 \pm 18.01$ (min: 18-max: 79)] with the diagnosis of CCHF were included into the study. Presenting complaints were fever (16/16, 100\%), fatigue (16/16, 100\%), bleeding (9/16, 56.2\%), petechial rash $(7 / 16,43.7 \%)$. nausea and vomiting $(6 / 16,37.5 \%)$. There was a history of tick contact in 14 cases $(87.5 \%)$ but not in two cases. Supportive treatment was applied to all cases, and droplet and contact isolation were applied. Blood product replacement was performed in five patients (31.2\%), and ribavirin was administered in nine patients (56.2\%). Mortality rate was 6.3\% (1/16).

Conclusion: Crimean-Congo Hemorrhagic Fever is an endemic disease in our country. Especially in spring and summer months, patients with fever and cytopenia on hemogram should be questioned, and tick contact should be sought.

Key Words: Crimean-Congo hemorrhagic fever; Tick; Ribavirin

\section{GiRiș}

Kırım-Kongo Kanamalı Ateși (KKKA), keneler tarafından tașınan, Bunyaviridae ailesinden Nairovirus grubundan tek sarmallı RNA virüsü olan Crimean-Congo haemorrhagic fever virüse bağlı ortaya cikar. Ates ve kanamayla seyreden zoonotik, multi-sistemik tutulum gösteren ciddi morbidite ve mortalite ile karakterize bir infeksiyon hastalı̆̆ıdır ${ }^{[1]}$.

Ülkemizde hastalığın asıl vektörü Hyalomma marginatum olarak kabul edilmektedir. Hastalı insanlara, virüs taşyan infekte kenelerin tutunmas1, bu kenelerin ezilmesi ile viremik hayvanların kan veya dokuları ile direkt temas sonucu bulaşabilmektedir. Ayrıca korunma önlemi almadan infekte hastanın kan veya dokularına temas veya laboratuvarda infekte materyal ile doğrudan temas ile de gecebilmektedir ${ }^{[2-4]}$.

Enkübasyon süresi kene tutunmasindan sonra genellikle 1-9 gün arasında değismektedir. İnfekte kan, vücut sıvısı ve diğer dokularla temas sonrasın- da 5-6 gün; en fazla ise 13 gün olabilmektedir ${ }^{[5]}$. Kene tutunma öyküsü, yaklașı \%70-75 hastadan alınabilmektedir. Hastalığın görüldüğü bölgelerde yașayan tarım ve hayvancllık ile uğrașan kișiler; kasaplar ve mezbaha calısanları; veteriner hekimler; askerler; korunması olarak kamp ve piknik yapanlar; KKKA hastaları ile temas eden sağlık personeli; laboratuvar çalısanları ve hasta yakınları risk grubunu olusturmaktadir ${ }^{[6]}$.

Kene tarafindan 1sirlma, infekte insan veya hayvan dokuları ile temas ve endemik bölgeye seyahat öyküsü, klinik semptom ve bulguların varlığında tanıdan süphelenilmelidir. Hastalığın tipik olarak dört evresi vardır; enkübasyon dönemi, prehemorajik dönem, hemorajik dönem ve iyilesme dönemi. Bu dönemlerin süreleri ve yakınmalar farkll11klar gösterebilmektedir ${ }^{[1]}$. Tam kan sayımında beyaz küre sayısında düsüus, trombositopeni, karaciğer fonksiyon testlerinde bozulma, kanama testlerinde uzama, böbrek fonksiyonlarında bozulma, $\mathrm{LDH}$ ve $\mathrm{CK}$ düzeylerinde artıs gibi non-spesifik laboratuvar bulguları inkübasyon döneminden 
itibaren tespit edilebilmekle beraber hemorajik dönemde belirgin olarak görülmekte ve konvalesan dönemden itibaren düzelmeye bașlamaktadır [7].

Hastalığın tedavisinin esasını destek tedavisi seçenekleri olușturmaktadır. Korunmaya yönelik etkinliği kanıtlanmıș bir așı veya etkene spesifik bir ilaç bulunmamaktadır. Hem tedavi hem de profilakside erken dönemde (ilk dört günde) ribavirin bașlanırsa etkinliğinin olabileceğine dair calıșmalar mevcuttur ${ }^{[8]}$. Hastalıkla mücadelede en önemli basamağı kișisel korunma önlemlerinin alınması olușturmaktadır.

Bu yazıda, kliniğimizde KKKA tanısı ile takip edilen olguların klinik ve laboratuvar bulgularının retrospektif olarak değerlendirilmesi ve ülkemizde endemik bir hastalık olarak akılda bulundurulmasinın hatırlatılması amaçlanmıștır.

\section{MATERYAL ve METOD}

Bu çalıșmada, kliniŏimizde 2009-2019 yılları arasında KKKA tanısı ile takip ve tedavi edilen olgular demografik özellikleri, bașvuru yakınmaları, kene öyküsünün varlığı, laboratuvar parametreleri, kan ürünleri replasmanı gerekliliği, hastanede yatıs süreleri, ribavirin tedavisi ve bir aylık sağ kalımları açısından retrospektif olarak hasta dosyalarındaki verilerden incelendi.

Hastanemize Kırım Kongo Kanamalı Ates tanı kodu (A98.0) ile giriși yapilan 33 olgu, Bilgi Sistemleri Müdürlüğü aracılığıyla retrospektif olarak tarand. Bu olgular içinde İnfeksiyon Hastalıkları ve Klinik Mikrobiyoloji Anabilim Dalı'nda takip ve tedavi edilerek, kesin tanısı konulan 16 olgu çalıșmaya dahil edildi. Kesin tanı, Halk Sağlığı Genel Müdürlüğü Laboratuvarına gönderilen kan örneklerinde calıșlan Polymerase Chain Reaction (PCR) testleri ile KKKA virüü RNA'sına bakılarak konuldu ${ }^{[9]}$.

Rutin laboratuvar parametrelerinden lökosit, hemoglobin, trombosit, kreatin kinaz (CK) ve C-reaktif protein (CRP) değerlendirmeye alınmıștır. Hastanemizde C-reaktif protein için referans aral1ğ1 0-0.5 mg/dL'dir. On sekiz yașında küçük olgular, serolojik incelemesi negatif olarak bulunanlar ve takibi bașka merkezde devam eden olgular calıșma dıșı bırakılmıștır. Dosyaları incelemek için Anabilim Dalından izin alınmıștır. Etik kurul onayı ve bilgilendirilmiș onam formu alınmadı.

\section{BULGULAR}

Kırım Kongo Kanamalı Ateși tanısı ile 16 olgu [on kadın, altı erkek, ortalama yas $50.37 \pm 18.01$ (min: 18-max: 79)] çalısmaya dahil edildi. Olguların bașvurduğu illerin dağılımına bakıldığında bes olgu (\%31.2) İzmir'den, dört olgu (\%25) Manisa'dan, üc olgu (\%18.7) Aydın'dan, birer olgu (\%6.2) Muğla, Balıkesir, Çorum ve Ordu'dan bașvurdu. Bes olgu (\%31.2) kırsal kesimde yașamaktaydı. Olguların bașvuru yakınmaları ates yüksekliği (16/16, \%100), halsizlik (16/16, \%100), kanama (9/16, \%56.2), peteșial tarzda döküntü (7/16, \%43.7) ve bulant1-kusma (6/16, \%37.5) seklindeydi. Kanama, bes olguda epistaksis, iki olguda ağız içi mukozada ve bir olguda intrakranial kanama olarak görüldui. Bașlangıçta olguların Glasgow Koma Skalası bir olguda 8, diğerlerinde 15 idi.

14 olguda (\%87.5) kene temas öyküsü bulunurken 2 olguda yoktu. Olguların hepsi, keneyi sağlık kurulușuna bașvurmadan kendileri çkardıklarını ifade ettiler. Kene altı olguda (\%42.8) alt ekstremitede saptandı. Hastalığın ortalama enkübasyon süresi $4.6 \pm 1.8$ gün (min: 2-max: 40) olarak bulundu. Ortalama lökosit, hemoglobin, trombosit, CK ve CRP değerleri sirasıyla $338410^{3} / \mu \mathrm{L}$ (930-12.000), $10.9 \mathrm{~g} / \mathrm{dL}$ (6-14), $48.11810^{3} /$ $\mu \mathrm{L}$ (1900-150.000), $1218 \mathrm{IU}(24-10.285)$ ve 5,5 $\mathrm{mg} / \mathrm{dL}(0.22-23)$ idi. Trombositopenisi olan 15 olgudan 14'ünde trombosit değerleri ortalama 4.28 günde (min: 2, max: 7) düzeldi. Tüm olguların serolojik incelemesi pozitif olarak sonuçandi.

Olguların hepsine destek tedavi uyguland, damlacik ve temas izolasyonu uygulanarak izlendi. Kan ürüleri replasmanı bes olguya (\%31.2) uyguland. Trombosit solüsyonu beș olguya, iki olguya taze donmus plazma, bir olguya eritrosit süspansiyonu verildi. Ortalama yatıs süresi 8.7 gündü (min: 2, max: 24). Ribavirin dokuz olguya (\%56.2) verilmiștir. İzlemde bir olguda eksitus gerçeklești. Mortalite oranı \%6.3'tü (1/16). Eksitus gelișen olguda trombositopeni düzelmemiș olup takibinde hemodiyaliz ihtiyac1 oldu. Ribavirin tedavisi verildi, takibinin ikinci günü eksitus ile sonuçlandı.

\section{TARTIŞMA}

Modern tıp literatüründe ilk kez 1944-45 yllarında Sovyetler Birliği'nde bir salgın sonrasında tanımlanan KKKA, ülkemizde ise ilk vaka 
2002 yilında Kelkit Vadisi'nde yer alan Tokat ilinde saptanmıștır ${ }^{[10,11]}$. Olguların coğunluğu 2008-2011 zaman diliminde yoğunlașmakla birlikte 2002-2017 yılları arasında Sağlık Bakanlığı tarafından doğrulaması yapılmıs 10562 vaka tanımlanmıștır ${ }^{[5,12]}$.

Hastalık ülkemizde bulaștırıcısı kene türünün yasam alanlarıyla uyumlu bir sekilde görülmektedir. Kırım-Kongo Kanamalı Ateși vakaları coğunlukla İc Anadolu'nun kuzeyi, Orta Karadeniz ve Doğu Anadolu'nun kuzeyinde yoğunlașmaktadır ${ }^{[1]}$. Ülkemizdeki vakaların yoğunlaștığı bölgeler göz önüne alındığında bizim çalıșmamızda sadece iki olgu (Çorum ve Ordu) dağılıma uymaktadır, diğer olgular vakaların daha nadir görüldüŭü bölgelerde saptanmıștır. Bu dağılım, olgu sayısı az olmakla birlikte vakaların belli bölgeler ile sınırlanmadığını ülkemizde her coğrafik bölgede KKKA'nın ortaya çkabileceğini desteklemektedir.

Kene 1sırı̆̆ı saptanan olgularda, kenenin vücuttan uzaklaștırılması ișlemi dikkatli bir sekilde yapılmalıdır. Kene parçalanmadan ve patlatılmadan, ince uçlu bir cimbızla, deriye yapıștığı yerden hafifçe sağa sola oynatılarak cıkarılmalıdır ${ }^{[13]}$. Kene kesinlikle elle çkarılmamalıdır. Kenenin elle cıkarılması; parçalanma veya ezilmesine neden olmakta ve infeksiyon gelișme riskini artırmaktadır. Ayrıca kenenin cıkarılma ișlemi, imkan dahilinde sağlık kuruluşlarında tecrübeli personel tarafından yapılmalıdır. Calıșmamızda kene öyküsü olan 14 olgu da keneyi sağlık kurulușuna bașvurmadan keneyi kendi eliyle çkarmıștır.

Günümüzde hastalığın 7-9. günlerinde enzim immun assay (EIA) veya indirekt immunofloresan antikor (IFA) yöntemi ile KKKA virüsüne özgül IgM ve IgG antikorları, saptanabilmektedir. Spesifik IgM duizeyleri, akut infeksiyonlarda, ortalama yedi günde yükselmekte olup 4 aydan sonra saptanabilir düzeylerin altına inmektedir. IgG, daha sonra yükselmeye bașlamakta ve bes yıla kadar saptanabilmektedir $^{[14]}$. Olgularımızın hepsi PCR ile serolojik olarak doğrulanmıstır. Böylece ayrıcı tanıdaki diğer viral hemorajik ates ile seyreden hastalıklar dișlanmıștır.

KKKA'da tedavi yaklașımı kanama diyatezinin kontrolü, destek tedavi (sıvı ve kan ürünleri rep- lasmanı), antiviral tedavi ve diğer steroid, intravenöz immunglobulin gibi tedavilerden olușmaktadır. Ribavirin, geniş spektrumlu antiviral aktiviteye sahip guanozin analoğudur. İndirekt etkisi, inosine monofosfat dehidrogenaz inhibisyonu ve immünomodülatör etki olup direkt etkisi polimeraz inhibisyonu, letal mutasyon ve mRNA engellenmesidir. İlk etkinlik 1989'da in-vitro olarak tanımlanmıștır. Sonraki yıllarda yapılan ceșitli çalıșmalarda da ribavirinin in-vitro etkinliğinin gösterildiği cok sayıda calıșma mevcuttur ${ }^{[15]}$. Calıșmamızda olguların \%56.2'sine bașvuru gününde oral ribavirin tedavisi bașlanmıstır.

Dünya'da yapılan calıșmalarda bildirilen mortalite oranı \%3-30 arasında değismektedir ${ }^{[16,17]}$. Ülkemizde de Türkiye Halk Sağlığı Kurumu verilerine göre 2002-2016 yılları arasındaki KKKA olgularında mortalite oranı \%4.8'dir ${ }^{[13]}$. Calışmamızda mortalite oranı ülkemize benzer, Dünya ortalamasının da alt sınırında olmak üzere $\% 6.25$ tir.

Çalıșmamızın en önemli kısıtlılığı örneklem sayısının az olması, uygulanan tedaviler açısından randomize kontrollü bir calıșma olmamasıdır.

Sonuc olarak KKKA, ülkemizde endemik olarak görülen bir hastalıktır. Özellikle bahar ve yaz aylarında ates yüksekliği ve hemogramda sitopeni saptanan hastalarda mutlaka kene ile temas sorgulanmalıdır ve muayenede aranmalıdır.

\section{ETIK KURUL ONAYI}

Etik kurul onayı alınmamıștır. Dosyaları incelemek için hastaların takip ve tedavi edildiği İnfeksiyon Hastalıkları ve Klinik Mikrobiyoloji Anabilim Dalından izin alınmıștır.

\section{ÇIKAR ÇATIŞMASI}

Yazarlar bu makale ile ilgili herhangi bir cıkar çatıșması bildirmemișlerdir.

\section{YAZAR KATKISI}
Anafikir/Planlama: MT, HP
Analiz/Yorum: DA, HAE, MT, HP
Veri sağlama: MT, HP, ORS
Yazım: DA, HAE, EEK
Gözden Geçirme ve Düzeltme: MT, HP, ORS
Onaylama: MT, HP, ORS 


\section{KAYNAKLAR}

1. Ergonul O. Crimean-Congo haemorrhagic fever. Lancet Infect Dis 2006;6:203-14.

2. Erbay A. Crimean-Congo Hemorrhagic Fever Virus in 'Manual of Security Sensitive Microbes and Toxins'. In: Dongyou Liu (ed). Florida: CRC Press, 2014:37-52.

3. Engin A. Kırım-Kongo Kanamalı Ateşi: Etken ve epidemiyoloji. Turkiye Klinikleri. J Inf Dis-Special Topics 2014;7(2):9-13.

4. Tülek N. Kırım-Kongo Kanamalı Ateşi: Tanı ve tedavi. Turk Klin J Inf Dis-Special 26 Topics 2014;7(2):19-28.

5. World Health Organisation (WHO). Epidemiology of Crimean-Congo haemorrhagic fever virus: Turkey, Russian Federation, Bulgaria, Greece, Albania, Kosovo. WHO. Accessed date: 11 August 2008. Available from: www.who.org.

6. Çiftci E. Ülkemizde yeni ortaya çıkan bir infeksiyon hastalı̆̆ı: Kırım Kongo Kanamalı Ateşi. Çocuk Enf Derg 2009;3:86-9.

7. Ergönül O, Celikbaş A, Dokuzoguz B, Eren S, Baykam N, Esener $\mathrm{H}$. Characteristics of patients with Crimean-Congo hemorrhagic fever in a recent outbreak in Turkey and impact of oral ribavirin therapy. Clin Infect Dis 2004;39:284-7.

8. Ozkurt Z, Kiki I, Erol S, Erdem F, Yilmaz N, Parlak M, et al. Crimean-Congo hemorrhagic fever in Eastern Turkey: Clinical features, risk factors and efficacy of ribavirin therapy. I Infect 2006;52:207-15.

9. Kazancıoğlu S, Akıncı E, Bodur H. Crimean-Congo Hemorrhagic Fever. Mediterr J Infect Microb Antimicrob 201 7;6:12.

10. Whitehouse CA. Crimean-Congo hemorrhagic fever. Antiviral Res 2004;64:145.

11. Gözalan A, Esen B, Fitzner I, Tapar FS, Ozkan AP, Georges-Courbot MC, et al. Crimean-Congo haemorrhagic fever cases in Turkey. Scand I Infect Dis 2007;39(4):332-6.
12. T.C. Sağlık Bakanlığı Halk Sağlığı Genel Müdürlüğü Zoonotik ve Vektörel Hastalıklar Dairesi Başkanlığı, KKKA istatistik verileri 2017.

13. Ergönül Ö. Viral kanamalı ateşler. In: Willke TA, Söyletir G Doğanay M, (eds). Infeksiyon Hastalıkları ve Mikrobiyolojisi. istanbul: Nobel Tip Kitabevleri, 2008:1251-65.

14. Shepherd AJ, Swanepoel R, Leman PA. Antibody response in Crimean Congo hemorrhagic fever. Rev Infect Dis 1989;11:801-6

15. Keshtkar-Jahromi $M$, Kuhn JH, Christova I, Bradfute SB, Jahrling PB, Bavari S. Crimean-Congo hemorrhagic fever: current and future prospects of vaccines and therapies. Antiviral Res 2011;90(2):85-92.

16. Ergönül Ö, Keske Ş, Çeldir MG, Kara iA, Pshenichnaya N, Abuova $G$, et al. Systematic review and meta-analysis of post exposure prophylaxis for Crimean-Congo hemorrhagic fever virus among healthcare workers. Emerg Infect Dis 2018;24(9):1642-8.

17. Gale P, Estrada-Pena A, Martinez M, Ulrich RG, Wilson A, Capelli $G$, et al. The feasibility of developing a risk assess ment for the impact of climate change on the emergence of Crimean-Congo haemorrhagic fever in livestock in Europe: a review. J App Microbiol 2010;108(6):1859-70.

\section{Yazıșma Adresi/Address for Correspondence}

Asistan Dr. Deniz AKYOL

Ege Üniversitesi Tip Fakültesi, İnfeksiyon Hastalıkları ve

Klinik Mikrobiyoloji Anabilim Dalı, İzmir-Türkiye

E-posta: yavuzleyla@hotmail.com 